\title{
When images lie: a variant of suprascapular artery found incidentally
}

\author{
Sunita Dinkar, Ganesh S Kamath, Vasudev B Pai
}

Kasturba Medical College, Manipal, Karnataka, India

\section{Correspondence to}

Dr Sunita Dinkar,

shunyata.dinkar@gmail.com

Accepted 18 August 2015

\section{DESCRIPTION}

Left internal thoracic artery (LITA) injection during coronary angiography of a 57-year-old man taken for coronary artery bypass graft showed a large branch arising very high from the LITA, about $1 \mathrm{~cm}$ past its origin. Even after harvesting the LITA to a very high extent to get this branch, it could not be found (figure 1). Hence, it was decided to dissect up to the origin of the LITA. The internal mammary vein accompanying the LITA was divided between ligaclips. This allowed clear visibility of the subclavian vein, which was then traced to its drainage into the internal jugular vein. The subclavian vein was obscuring vision of the left subclavian artery (SCA) and LITA, hence it was looped and pulled up to define all the branches of the first part of the SCA. The origin of the LITA was normal, opposite the origin of the left thyrocervical trunk, and the costocervical trunk was absent. Another branch was seen arising directly from the SCA, 1-2 mm lateral to the origin of the LITA, going across the phrenic nerve, parallel to the first rib (figure 2). The initial course of this artery is similar to suprascapular artery which usually arises higher as a branch of TCT, but in this case has a direct origin from SCA. Though reported in anatomical dissections in literature, the direct origin of suprascapular artery from left subclavian artery has not been reported in actual patients.

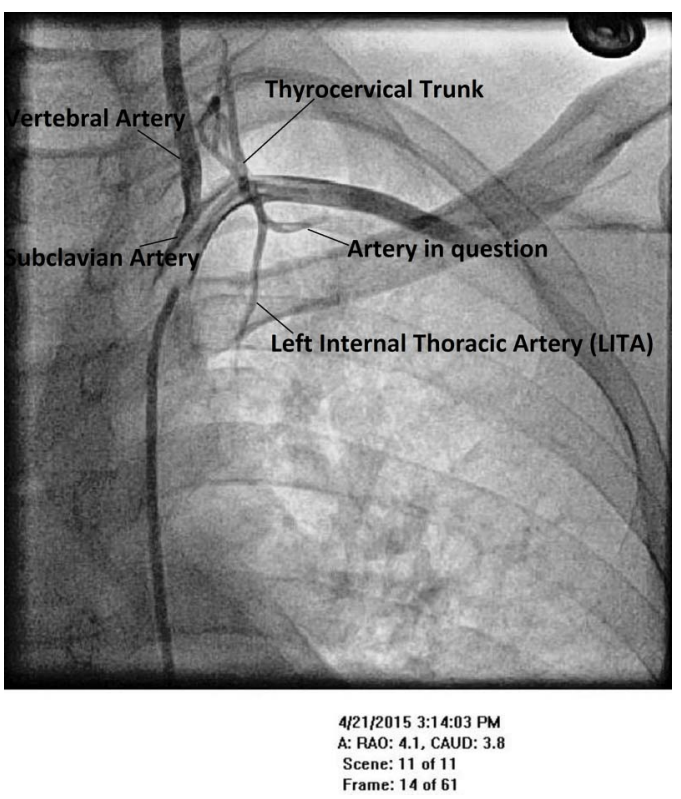

Figure 1 Angiography of left internal thoracic artery showing a large branch arising very high past it, immediately after its origin from subclavian artery.

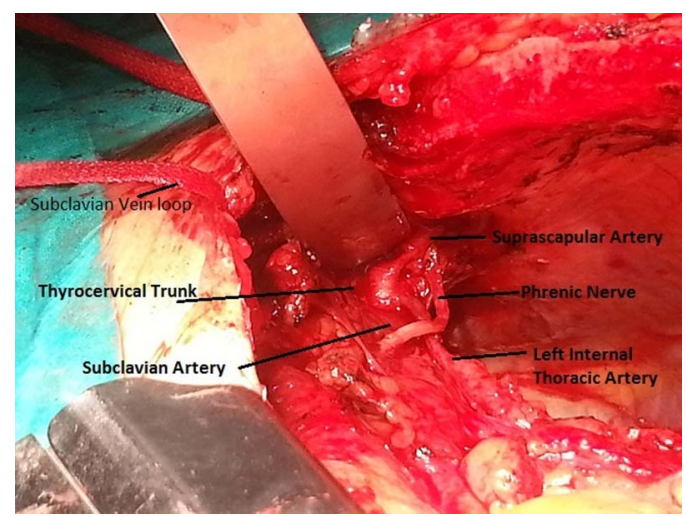

Figure 2 Per-operative photograph of left internal thoracic artery (LITA) dissected up to its origin from subclavian artery with thyrocervical trunk originating opposite it. An additional branch arising directly from subclavian artery next to origin of LITA.

It was this branch, mistakenly seen, on angiography, to be arising from the LITA. On the basis of the findings, we concurred it was a suprascapular artery, an anatomical variation of its origin. The discrepancy between reading the angiography and operative findings occurred because of the view, the particular angle where it overlapped with the LITA because of its proximity to the LITA.

The reported variation in origin of suprascapular artery is $13.16 \%$ from SCA with $50 \%$ from first part. ${ }^{1}$ Although challenging to dissect that high, it was important to continue, as, being that close to the LITA, it could steal flow from the LITA and cause postoperative ischaemia. ${ }^{23}$

\section{Learning points}

- Undetected variation in the left internal thoracic artery (LITA) may steal flow from the LITA and cause ongoing postoperative ischaemia, especially if a large branch is too close to the LITA. ${ }^{23}$

- The angle of LITA injection should be kept in mind during analysis. A second injection of the LITA should be taken from a different angle if a high or proximal branch is seen.

- Discrepancy between angiography and clinical findings is challenging for the surgeon but worth pursuing if a large branch is seen near the LITA, to avoid a second intervention, and financial hardship and mental agony for the patient.

Acknowledgements The authors would like to acknowledge Dr Guruprasad Rai and the CVTS team. 
Competing interests None declared.

\section{Patient consent Obtained.}

Provenance and peer review Not commissioned; externally peer reviewed.

\section{REFERENCES}

1 Ronald A, Bergman, Adel K, et al Illustrated Encyclopedia of Human Anatomic Variation: Opus II: Cardiovascular System. Arteries: Head, Neck, and Thorax,
Suprascapular Artery, fig. 316. http://www.anatomyatlases.org/AnatomicVariants/ Cardiovascular/Text/Arteries/Suprascapular.shtml

2 Feit A, Reddy CV, Cowley C, et al. Internal mammary artery angiography should be a routine component of diagnostic coronary angiography. Cathet Cardiovasc Diagn 1992;25:85-90.

3 Andreou AY, lakovou I, Vasiliadis I, et al. Aberrant left internal thoracic artery origin from the extrascalenic part of the subclavian artery. Exp Clin Cardiol 2011;16:62-4

Copyright 2015 BMJ Publishing Group. All rights reserved. For permission to reuse any of this content visit http://group.bmj.com/group/rights-licensing/permissions.

BMJ Case Report Fellows may re-use this article for personal use and teaching without any further permission.

Become a Fellow of BMJ Case Reports today and you can:

- Submit as many cases as you like

- Enjoy fast sympathetic peer review and rapid publication of accepted articles

- Access all the published articles

- Re-use any of the published material for personal use and teaching without further permission

For information on Institutional Fellowships contact consortiasales@bmjgroup.com

Visit casereports.bmj.com for more articles like this and to become a Fellow 